\title{
Haemato-Biochemical Alterations in Tuberculin Positive Dogs
}

\author{
Acheenta G. Barua ${ }^{1 *}$, Koushik Kakoty ${ }^{2}$, Uttam Rajkhowa ${ }^{1}$, \\ Pranjal M. Nath ${ }^{1}$ and Nur Abdul Kader ${ }^{1}$
}

${ }^{1}$ Department of Veterinary Public Health, College of Veterinary Science, Assam Agricultural University, Khanapara, Guwahati-781022, India

${ }^{2}$ Department of Veterinary Public Health, College of Veterinary Science, Assam Agricultural University, Joyhing, North Lakhimpur- 787051, India

*Corresponding author

\section{A B S T R A C T}

\section{Keywords}

Blood, biochemical, dog, reactor, tuberculosis

\section{Article Info}

Accepted:

25 February 2020 Available Online: 10 March 2020
A total of 368 dogs brought to the Teaching Veterinary Clinical Complex, Guwahati, Assam, India were screened for tuberculosis using tuberculin skin test (TST) technique and out of which a total of 6 dogs each from both the reactor and non-reactor group were included for the study. Hemogram of tuberculin positive reactors revealed significant $(P \leq 0.05)$ reduction in $\mathrm{Hb}, \mathrm{PCV}$, TEC, TLC, neutrophils and MCHC when compared to tuberculin negative reactors. Alterations in biochemical parameters included significant $(P \leq 0.05)$ increase in serum Aspartate transaminase (AST), Alanine transaminase (ALT) and Alkaline phosphatase (ALP) and serum calcium concentrations and reduced serum albumin and inorganic phosphorous.

\section{Introduction}

Among several closely related species causing tuberculosis (TB) in humans and animals, the most important are M. tuberculosis and $M$. bovis (Pesciaroli et al., 2012). Companion animals (mainly dog) living in contact with TB patients are at great risk of exposure to this pathogen (Snider et al., 1971). Dogs may also occasionally suffer from tuberculosis caused by $M$. tuberculosis, for which a human considered the only reservoir host Typically, canine TB is a chronic disease affecting lungs and regional lymph nodes, however, lesions have been described also in many other organs (Greene et al., 2012).

Tuberculin testing has traditionally been used to determine the prevalence of infection in animals and human. Variation in the blood picture is a good aid in the diagnosis and prognosis of a disease and as such it has been a subject of study in several diseases of animals. The present study was taken up to 
understand the correlation between different hematological features in the typical cases of tuberculosis in dogs with that of non-reactors.

\section{Materials and Methods}

A total of 368 dogs brought to the Teaching Veterinary Clinical Complex, Guwahati, Assam, India were screened for tuberculosis using tuberculin skin test (TST) technique. Prior to the TST, dogs were sedated with Thiopental Sodium $(25 \mathrm{mg} / \mathrm{kg}$, i/v) (Thiosol 1gm, Neon Laboratories Ltd., Mumbai, India). The TST was done by 3 intradermal injections of $0.1 \mathrm{ml}$ of 2TU, 5TU and 10TU of Tuberculin PPD (Arkray Healthcare Ltd., Gujrat, India) in the medial aspect of thigh. Skin thicknesses were measured at both sites before the intradermal injection and after 72 hrs. If the skin thickness is more than $5 \mathrm{~mm}$, it is considered as positive (OIE). A number of 6 dogs each, irrespective of breed and age from both the positive reactors and nonreactors were randomly selected for studying the hematological and biochemical changes.

The whole blood samples were collected in clean and dry tubes with and without anticoagulant (EDTA at 1-2mg per $\mathrm{ml}$ of blood), for studying haemogram and biochemical parameters in post intra dermal injection of tuberculin. The following parameters were studied as per the standard techniques (Jain et al., 1975). Packed Cell Volume (PCV), Total Erythrocyte Count (TEC): Total Leukocyte Count (TLC): Hemoglobin Concentration (Hb), Differential Leukocyte Count (DLC), Mean Corpuscular Hemoglobin (MCH), Mean Corpuscular Volume (MCV), Mean Corpuscular Hemoglobin Concentration (MCHC).

Serum samples were subjected to estimate total serum proteins, Albumin, Globulin, Serum calcium, Serum inorganic phosphorous, Blood Urea Nitrogen (BUN), creatinine, sodium, potassium, chlorine, Aspartate transaminase (AST), Alanine transaminase (ALT) and Alkaline phosphatase (ALP) by using Vet Scan (VS 2 ). Results ofthe studies were analyzed statistically adopting student " $t$ " test for significance.

\section{Results and Discussion}

\section{Haemogram}

The results of hematological evaluation of tuberculin test positive reactors $(n=6)$, and non-reactors $(n=6)$ have been presented in Table. 1. There was an increase in mean corpuscular volume, eosinophil \& monocyte number and decrease in total erythrocyte count \& hemoglobinin tuberculin test positive reactors. There was also increase in mean hemoglobin concentration and decrease in Packed cell volume and Mean corpuscular hemoglobin concentration, which were statistically significant $(P \leq 0.05)$.

Decreased values of packed cell volume (PCV), Hemoglobin (Hb) \& Total erythrocyte count (TEC) were observed in the tuberculin reactors as well as in animals with tubercular lesions (Ariyibi et al., 2002). This decrease in $\mathrm{PCV}, \mathrm{Hb}$ and TEC values could be attributed to poor health condition and chronicity of the disease. The leukocyte count was statistically insignificant $(P \leq 0.05)$ in the present study. However, slightly higher values of Total leukocyte count (TLC) and lymphocytes and lowered neutrophil count recorded in reactors when compared to nonreactors.

Considerable variation in Haemogram of tubercular animals and reactors could beattributable to the advanced stage of thedisease. Monocytosis was a common picture observed in blood samples of tubercular dog whereas there was a significant rise of monocytes compared to nonreactors. 
Monocytes have an important role in the cellular response to the tubercle bacillus and it is responsible for degradation of the phospholipids of the bacterial cell wall, monocytes later transforms into epithelioidcell which is a characteristic feature intubercular granulomas (Kaufmann 1990). Hencemonocytosis can be regarded as an evidence of active extension of tuberculous process.

The present study revealed significant $(P \leq 0.05)$ increase in eosinophil percentage in the reactor group which probably the indicative of a benign period in the course of the disease; where as some of the researchers did not observe eosinophilia (Holman et al., 1950).

\section{Biochemical studies}

The changes in the various biochemical constituents of serum in tuberculin test reactors and non-reactors have been summarized in Table 2. The results indicated that there was no significant difference in the total protein contents between the reactors and non-reactors but there was significant difference in the level of albumin, globulin and $\mathrm{A} / \mathrm{G}$ ratio $(P \leq 0.05)$. Albumin content in the serum of reactors was significantly $(P \leq 0.05) \quad$ decreased as compared to nonreactors. However, significant increase in globulin content was observed in reactors when compared to nonreactors, which resulted in alteration in $\mathrm{A} / \mathrm{G}$ ratio.

There was increase in the levels of AST, ALT, alkaline phosphatase and serum calcium and decrease in inorganic phosphorous, which were statistically significant $(P \leq 0.05)$, which is similar with the findings of Engelmann et al., (2014).Reactors showed significant increase in the levels of transaminases which could be due to process of necrosis or degeneration taking place in the body (Carrol, 1963).

Table.1 Haemogram in Tuberculin Positive and Negative Reactor dogs [Mean \pm SE]

\begin{tabular}{|c|c|c|}
\hline Parameters & Reactor $(n=6)$ & Non-reactor $B(n=6)$ \\
\hline $\mathrm{Hb}(\mathrm{g} / \mathrm{dl})$ & $10.74 \pm 1.62 *$ & $14.38 \pm 1.25$ \\
\hline PCV (\%) & $33.11 \pm 7.04^{*}$ & $43.53 \pm 2.30$ \\
\hline TEC (x106/ $\mu \mathrm{l})$ & $4.11 \pm 0.41 *$ & $6.86 \pm 0.43$ \\
\hline $\operatorname{MCV}(\mathbf{f L})$ & $77.69 \pm 7.87 *$ & $63.71 \pm 5.83$ \\
\hline $\operatorname{MCHC}(\mathrm{g} / \mathrm{dl})$ & $27.73 \pm 2.21 *$ & $33.62 \pm 2.82$ \\
\hline $\operatorname{TLC}\left(\times 10^{3} \mu \mathrm{I}\right)$ & $17.85 \pm 0.96$ & $17.01 \pm 2.33$ \\
\hline Neutrophils (\%) & $71.98 \pm 2.26^{*}$ & $81.38 \pm 1.69$ \\
\hline Lymphocytes (\%) & $16.55 \pm 1.64$ & $15.64 \pm 2.47$ \\
\hline Eosinophil (\%) & $7.01 \pm 0.36 *$ & $1.15 \pm 0.42$ \\
\hline Monocyte (\%) & $4.01 \pm 0.27 *$ & $0.41 \pm 0.21$ \\
\hline
\end{tabular}

*= Significant $(P \leq 0.05)$ difference as compared to Negative Reactors within same row 
Table.2 Biochemical studies in tuberculin positive and negative reactor dogs [Mean \pm SE]

\begin{tabular}{|c|c|c|}
\hline Parameters & Reactor $(\mathbf{n}=\mathbf{6})$ & Non-reactor $(\mathbf{n = 6})$ \\
\hline AST (IU/L) & $83.33 \pm 5.31^{*}$ & $58.28 \pm 3.97$ \\
\hline ALT (IU/L) & $30.33 \pm 4.07$ & $25.54 \pm 4.21$ \\
\hline ALP (IU/L) & $119.14 \pm 8.17^{*}$ & $91.35 \pm 6.15$ \\
\hline Albumin (g/L) & $2.95 \pm 0.48^{*}$ & $3.98 \pm 0.47$ \\
\hline Globulin (g/L) & $3.66 \pm 0.45^{*}$ & $2.56 \pm 0.43$ \\
\hline A/G Ratio & $0.806 \pm 0.24 *$ & $1.554 \pm 0.22$ \\
\hline BUN (mg/dl) & $17.26 \pm 5.21$ & $17.37 \pm 5.02$ \\
\hline Creatinine (mg/dl) & $0.83 \pm 0.36$ & $0.96 \pm 0.47$ \\
\hline Ca (mg/dl) & $10.92 \pm 0.89 *$ & $8.68 \pm 1.45$ \\
\hline P (mg/dl) & $3.87 \pm 0.33 *$ & $5.13 \pm 2.37$ \\
\hline Na (mEq/L) & $142.66 \pm 9.33$ & $141.92 \pm 7.40$ \\
\hline K (mEq/L) & $4.53 \pm 0.67$ & $4.03 \pm 1.20$ \\
\hline Cl (mEq/L) & $115.54 \pm 6.52$ & $114.89 \pm 8.65$ \\
\hline * Significant $(P \leq 0.05)$ difference as compared to Negative Reactors within same row \\
\hline
\end{tabular}

*= Significant $(P \leq 0.05)$ difference as compared to Negative Reactors within same row

Significant difference in total protein values, BUN, creatinine, sodium, potassium and chlorine were not seen between reactors and non-reactors in the present study.

Though dynamics of tuberculosis between human and dog can be better understood by isolation and identification of the pathogen, the alterations in hematological and biochemical values can be a significant indicator in tuberculosis.

\section{Acknowledgement}

Authors are thankful to Department of Biotechnology for funding the "Molecular Epidemiology of Canine Tuberculosis in Assam, neighboring States and its Containments" and Director of Research (Veterinary) for necessary facilities to carry out the research.

\section{References}

Ariyibi A.A., Oyeyemi M.O. andAjadi, R.A., 2002.A comparative study of some hematology and biochemical parameters of clinically healthy Alsatian and local dogs.African Journal of Biomedical Research, 5:145-147.

Carrol E.J., 1963. In: Clinical bio-chemistry of domestic animals. J. Academic Press, New York.

Engelmann N. Ondreka N., Michalik J. and Neiger R., 2014.Intra-abdominal Mycobacterium tuberculosis Infection in a Dog.J. Vet. Intern. Med., 28:934938.

Greene C.E. and Gunn-Moore D.A., 2012. Infections caused by slow-growing Mycobacteria. In: Greene CE, editor. Infectious diseases of the dog and cat. 4th ed. Philadelphia: Elsevier, pp. 495-515. 
Holman H.H., 1950. Clinical haematology:Diagnostic methods in Veterinary Medicine. Boddie, G.I., 3rd Edn. 3 Oliver and Boyd Ltd. Edinburg. pp. 322-356.

Jain N.C., Schalm O.W. and Carroll E.J., 1975.Veterinary Hematology (3rd Edn).Lea and Febiger. Philadelphia, pp. 15-81.

Kaufmann S.H.E., 1990. Immunity to mycobacteria.Res.Microbiol., 141: 765768.
OIE terrestrial manual, Bovine tuberculosis, Chapter 2.4.6, http://www.oie.int/en/ international-standard-setting/terrestrialmanual/access-online

Pesciaroli M., Alvarez J., Boniotti M.B., Cagiola M., Di Marco V., Marianelli C., Pacciarini M. and Pasquali P., 2014.Tuberculosis in domestic animal species.Res. Vet. Sci., 97:78-85.

Snider W. R., 1971. Tuberculosis in canine and feline populations.American Review of Respiratory Disease, 104:877-887.

\section{How to cite this article:}

Acheenta G. Barua, Koushik Kakoty, Uttam Rajkhowa, Pranjal M. Nath and Nur Abdul Kader. 2020. Haemato-Biochemical Alterations in Tuberculin Positive Dog. Int.J.Curr.Microbiol.App.Sci. 9(03): 2997-3001. doi: https://doi.org/10.20546/ijcmas.2020.903.343 